\title{
JUDICIAL ASSESSMENT OF THE Credibility of Child Witnesses
}

\author{
Nicholas Bala, Karuna Ramakrishnan," \\ RODERICK LINDSAY ${ }^{\circ \cdot}$ AND KANG LET: ${ }^{\cdots \cdot}$
}

This article reports on the results of wo research studies carried out by the authors that address the questions of how and how well judges assess the honesty and reliability of children's testimony. One study tested the accuracy of jutges and other professionals in assessing the honesty of children giving mock testimony. Judges performed at only slightly above chance levels, though the performance of judges was comparable to other justice system professionals, and significamly better than the performance of law students.

The second study, a survey of Canadian judges about their perceptions of child witnesses, reveals that judges believe that compared to adults, children are generally more likely when testifying to make errors due 10 limitations of their memory or communication skills and due to the effects of suggestive questions. However, children are perceived to generally be more honest than adult wilnesses. The survey also revealed that judges believe that children are offen asked developmentally inappropriate questions in court. especially by defence counsel. There were no gender differences among the judges in eilher sfudy:

To put this research in context. the arficle first discusses the inheremt challenges in assessing the credibility of witnesses and provides a review of the psychological literature and leading Canadian jurisprudence on the credibility and evidence of children.
Larficle traite des risuliais de deux projets de recherche des auteurs abordant la mesure dans laquelle les juges ivaluent bien thomnetete et la fiabiliki des rimoignages d'enfants. Une étude a verifié la mesure dans laquelle les juges el autres professionnels éaient corrects dans leur évaluation de l'homèteli duram des rémoignages ficlifs. La performance des juges, bien que comparable à celle des autres professionnels du système de justice, étail a peime supiricure anx nueaux di hasard ef considerablemem meilleure à celle des éfudiams en droit.

La deuxieme sinde, wn sondage sur la perception que les juges canadiens ont des enfants rémoins, révèle que les,juges esiment que. par rapport aux adihes. les enfanis son généralemem plus enclins à faire des erreurs en rimoignam en raison des limiles de mémoire. du manque de compélences en communcalion ou de l'effer des questions suggestives. Toutefors. on percoit habinellement les enfants comme itam plus honnètes que les adultes qui temoignent. le sondagi a aussi rivili que les juges croient que ton prose sowvent des questions inapproprices anx enfanis comple tenu de leur mvean de developpement. surlout de la part des avocats de la defense. Aucume des deux ifudes n'a rivelé de differences entre les seres des juges.

Pour mettre cette recherche en contexte. I'arricle traile d abord des problèmes liès à l'évaluation de la crédibilité des témoins el revoit la documentation sur la psychologie et la principale jurispridence canadienne en marière de crédibilité et de prewve des enfants.

\section{TABle of Contents}

I. INTRODUCTION . . . . . . . . . . . . . . . . . . . . . . . . . 996

II. THE CHALlenge of Assessing CRidiblLITY . . . . . . . . . . . . . . . . 997

III. Psychological ReseArCh ON CHII.D Witnesses . . . . . . . . . . 999

- Faculty of Law. Queen's University. Kingston. Ontario The authors would like to ackinowledge the support of a grant from the Social Sciences and Humanities Research Council ol Canada. and to thank the participants in the studies reported here.

-. Asticling Student, Ontario Ministry of the Attorney Genteral

-.. Department of Psychology, Queen's University.

...* Department of Psychology, University of California, San Diego. 
IV. RESEARCH ON JUDGING CREDIBILITY AND

Detecting LIES ........................... 1001

V. CANADIAN JURISPRUDENCE ON CREDIBILITY

ASSESSMENT OF CHILD WITNESSES $\ldots \ldots \ldots \ldots \ldots \ldots \ldots \ldots . \ldots \ldots$

VI. CURRENT ProJect: TWO STUdIES ON JUdiCIAL

ASSESSMENTS OF CHI.D WITNESSES . . . . . . . . . . . . . . . 1007

A. STUDY ON ACCURACY OF JUSTICE PROFESSIONALS

IN ASSESSING HONESTYY OF CHII.DREN . . . . . . . . . . . 1007

B. StUdy ON JUdicial. Perceptions OF

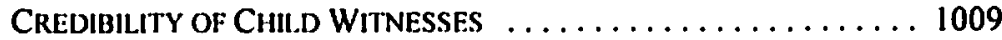

VII. DISCUSSION OF RESULTS ....................... 1014

VIII. IMPLICATIONS FOR THE JUSTICE SYSTEM $\ldots \ldots \ldots \ldots \ldots \ldots \ldots \ldots 1016$

\section{INTRODUCTION}

Until the 1980s, the Canadian justice system made it very difficult for children to testify and displayed deep suspicion of their testimony. There has been much change in the treatment of child witnesses in Canada's criminal justice system over the past two decades, and children now regularly testify,' but there continues to be controversy about children's testimony. ${ }^{2}$ A central question, but one that has been the subject of little explicit commentary or research, is how effective judges are in assessing the testimony of child witnesses. This article provides some preliminary answers to this question, reporting on the results of research carried out by the authors that addresses how and how well judges assess the honesty and reliability of children's testimony.

One study that we conducted tested the accuracy of judges and other professionals in assessing the honesty of children giving mock testimony. The other study was a survey of Canadian judges about their perceptions of child witnesses. Judges performed at only slightly above chance levels on our test of their accuracy at detecting the honesty of child witnesses, though the performance of judges was comparable to other justice system professionals, and was significantly better than the performance of law students. The veracity assessment test in this study was challenging because children only gave relatively brief testimony, and these results should not be interpreted as indicating that judges in court actually perform at only slightly above chance level in assessing the honesty of child witnesses, though our study clearly established that judges are not "human lie detectors." Our second study, a survey of the attitudes of judges, reveals that judges believe that compared to adults, children are generally more likely when testifying to make errors due to limitations of their memory or communication skills and due to the effects of suggestive questions, but that children are

I Sec e.g. Nicholas Bala. "Double Victims: Child Sexual Abuse and the Canadian Criminal Justice System" (1990) 15 Queen's L.J. 3 [Bala, "Double Victims"]: Nicholas Bala. "Child Witnesses in the Canadian Criminal Justice System; Recognizing Their Needs \& Capacities" (1999) 5:2 Psychol. Pub. Pol 'y \& L. 323-54; and N. Bala, R.C.L. Lindsay \& E. MeNamara, "Testimonial Aids for Children; The Canadian Experience with Closed Circuit Television. Screens and Videolapes" (2001) 44 Crim. L.Q. 461.

: See e.g. David M. Paciocco. "The Evidence of Children: Testing the Rules Against What We Know" (1996) 21 Queen's L.J. 345. 
perceived to generally be more honest than adult witnesses. The survey also revealed that judges believe that children are often asked developmentally inappropriate questions in court, especially by defence counsel, which affects the quality of the testimony that children give. There were no gender differences among the judges in either study.

To put our empirical work in context, we begin with a discussion of the inherent challenges in assessing the credibility of witnesses. Next, we review the psychological literature about child witnesses and the assessment of their credibility, and consider leading Canadian jurisprudence on the assessment of the evidence of children. We then present the results of our two studies and conclude with a discussion of some of the implications of this research for the justice system and for the education of judges.

\section{The Challenge of Assessivg Credibility}

More than half a century ago, the American legal scholar, Jerome Frank, recognized the inherent indeterminacy in assessing the credibility of any witness.

$[W]$ henever there is a question of the credibility of witnesses - of the believability, the reliability, of their lestimony - then, unavoidably the irial judge or jury must make a guess about the facts. ${ }^{3}$

There is generally no way to be absolutely certain whether any witness is telling the "truth" - that is, giving an accurate description of what the witness saw or heard. Indeed, few witnesses are completely inaccurate or wholly dishonest in every aspect of their testimony, and no witness can be totally accurate and complete in every statement made about a past event.

Assessments of credibility are carried out by a number of different actors in the criminal justice system. An initial assessment of credibility is made during the investigation stage of a criminal case by the police, who in Canada typically have the responsibility for whether to lay a charge and commence a prosecution. In cases involving child abuse victims, a social worker employed by a child welfare agency often also will have a role in this initial investigative interview, deciding whether a child protection proceeding will be commenced and perhaps providing advise to the police about the commencing of a criminal prosecution. Crown prosecutors are expected to interview child witnesses before they testify (though this does not always happen in practice). Even if the prosecutor believes that the child is telling the truth, the prosecutor may decide that a case should not proceed to trial because the child is not likely to be perceived as "credible" by a trier of fact, who may not fully appreciate issues around children's testimony or because some supportive evidence, such testimony from other victims, may not be admissible in court. ${ }^{4}$ If a case proceeds to trial, the trier of fact must decide which elements of the testimony of each witness about the central matters at issue are to be regarded as "credible"; that is, to what extent the testimony can be relied upon in making a decision.

Jerome Frank. Courts on Trial (Princeton: Princeton University Press. 1949) at 16.

Police and prosecutors may be aware of other victims whose stories strongly support the evidence of' a particular complainant, but this supportive evidence may not be adinissible as "similar faet" evidence and the court will be left to consider only the evidence of one child, whose testimony may he inadequate to secure a conviction: see e.g. R. v. R.B. (2003). 68 O.R. (3d) 75 (C.A.). 
While the different aspects of credibility assessment are rarely explicitly analyzed in reported judgments, we posit that credibility assessment involves the consideration of several different aspects of the testimony of a witness: ${ }^{5}$

Honesty: Is the witness making a good faith effort to fully and accurately give evidence, or conversely, is the witness deliberately lying or at least not disclosing certain information?

Memory: How accurate and complete is the memory of the witness?

Suggestibility: Has the memory of the witness been distorted as a result of conversations or questions with others?

Communication Ability: How well does the witness understand the questions and how well is the witness able to communicate about the matters at issue?

A trier of fact may rely on a number of factors when assessing the credibility of a witness, including:

The (in)compatibility of the witness's testimony with other evidence in the case; ${ }^{6}$

- The demeanour of the witness while giving testimony, including such matters as the manner of speech, pauses, physical demeanour and apparent confidence of the witness;

Whether the witness tells a consistent story, or conversely, becomes selfcontradictory;

Whether the testimony "makes sense" - that is, how consistent is the testimony with the understandings of the trier of fact about what happens in the world and how people act in different situations;"

Whether or not the witness has a general reputation for honesty or dishonesty. ${ }^{10}$

For summary and analysis of case law on credibility assessment, sec e.g. Alan W. Mewett \& Peter J. Sankoff. Wilnesses (Carswell: Toronto, 1991 \& updaled) c. II and S. Casey Hill et al.. McWilliams Canadian Criminal Evidence (Aurora, Ont: Canada Law Book. 2004) c. 27.

On the need for a judge to explain why testimony of child complaint is preferred to testimony of an accused, ste e.g. R. v Y.M. (2004), 187 O.A.C. 101 (C.A.).

Appeal courts have emphasized that trial judges should not place much emphasis on witness demeanour, especially when dealing with child witnesses: seve e.g. R. v. Norman (1993), 16 O.R. (3d) 295 (C.A.) [Norman]: and R. v. Levert (2001), 59 C.C.C. (3d) 71 (Ont. C.A.) (Leverr].

Inconsistencies in a child's lestimony may be significant, but judges strould take account of a child's capacities; sec e.g. R. v. C.S.M., 2004 NSCA 60; and R. v. Mimuskin (2003), 68 O.R. (3d) 577 (C.A.). Levert, supra note 7 at para. 16: "jurors [can rely] ... upon their common sense and experience with clildren ... [when] determin[ing] the weight to give to this testimony."

The fact that a child witness, or any witness, has told lies in non-court settings does not mean that their testimony in court must be discounted; see e.g. Levert. supra note 7. 
The consideration of these factors by a trier of fact will inevitably be influenced by the personality, education, intelligence, personal experiences and values of the trier of fact."

\section{Psychological Research on Child Witnesses}

There has been a significant amount of psychological research about the memory, suggestibility and communication capacity of children, and the discussion offered here is only intended to summarize a large and complex body of literature.

Research establishes that while children can be reliable witnesses, children's memories are less well developed than adult memories. ${ }^{12}$ Children are more suggestible than adults and they have greater difficulty than adults in communicating what they know. There is no research, however, that compares the honesty of children and adults.

As children become older, their memory improves. Even children as young as four years can provide accurate information about what happened to them one or even two years earlier. ${ }^{13}$ Interestingly, while older children and adults can give more information about past events that happened to them than younger children, older children are also more likely to provide inaccurate information about past events than younger children.

Research also reveals that children are more likely to consistently recall information about the core elements of an experience than about peripheral elements, ${ }^{14}$ and thus inconsistencies about peripheral elements (such as descriptions of clothing or setting) in their stories may not be an important marker for the veracity or accuracy of their testimony with regard to central elements of what happened to them.

A major concern with child witnesses is their potential suggestibility. As a result of repeated or misleading questions, the memory of a witness may become distorted. It is possible for a person who has been subjected to repeated, suggestive questioning to develop "memories" of events that did not in fact occur. While children, especially young children. are more suggestible than adults, there is great variation between individuals of the same age in suggestibility and in resistance to suggestion. There is a large body of experimental research about the suggestibility of children, ${ }^{15}$ as well as some research about the suggestibility of adults.

Ronald J. Allen \& Gerald T.G. Seniuk. "Two Puzzles of Juridical Proof" (1997) 76 Can. Bar Rev. 65. Maggie Bruck, Stephen J. Ceci \& Helene Hembrooke, "Reliability and Credibility of Young Children's Reports from Research to Policy and Practice" (1998) 53:2 American Psychologist 136.

See e.g. Carole Peterson, "Children's Long-term Memory for Autobiographical Events" (2002) 22 Developmental Review 370.

Carole Peterson, Lisa Moores \& Gina White, "Recounting the Same Events Again and Agaın Children's Consistency Across Mulliple Interviews" (2001) is Applied Cognitive Psychology 353

For reviews, see e.g. Bruck. Ceci \& Hembrooke, supra note 12 at 144: Thomas D Lyon. "Applying Suggestibility Research to the Real World: The Case of Repeated Questions" (2002) 65 I.aw \& Contemp. Probs. 97. Perhaps the most infamous Canadian example of the damage that can occur frum highly suggestive police interviews of children arose from an investigation in Martensville. Saskatchewan in the early 1990s: see $R$. v. Sterling (1993). 102 C.C.C. (3d) 481 (Sask. C A.) Sete also) State v. Michaels, 642 A.2d I372 (N.J. Sup. Ct. 1994). 
The way in which children are questioned can also greatly affect what they are able to communicate. Research studies reveal that children and adults generally provide more information in response to specific questions rather than to the open-ended questions that are typically posed during direct examinations of witnesses. ${ }^{16}$ Children, especially young children, may lack the cognitive capacity to provide meaningful and consistent answers to questions that involve frequency of events, time or size, or that require explanation of motive (why questions), though if asked they will usually try to answer. In addition, "yes or no" questions are problematic as children, especially young children may have a bias to produce "yes" answers, and when asked such questions by unfamiliar adults, young children will rarely respond with "I don't know."

Children, especially young children, are socialized to provide responses to questions, even if they do not fully understand what is being asked. Children who are asked questions that they do not fully understand will usually attempt to provide an answer based on the parts of the question that they did understand, so that a child's answer to a question may seem unresponsive or may even be misleading. ${ }^{18}$

There are questioning techniques that can increase the accuracy and completeness of the testimony of children, such as showing warmth and support to children, mimicking the vocabulary of the child, avoiding legal jargon, confirming meanings of words with children, limiting use of yes/no questions and avoiding of abstract conceptual questions. ${ }^{19}$ As well, preparing children for court and providing them with memory retrieval strategies can increase recall of details. ${ }^{20}$

When repeatedly interviewed about an experience older children tend to provide a more consistent description and to provide more information. ${ }^{21}$ However, children, especially younger children, tend to assume that if the same question is repeated, the original answer must have been incorrect. So young children who are repeatedly asked the same questions

Karen J. Saywitz et al, "Children's Memory of a Physical Examination Involving Genital Touch: Implications for Reports of Child Sexual Abuse" (1991) 59 Journal of Consulting and Clinical Psychology 682; Karen J. Saywitz \& Thomas D. Lyon, "Coming to Grips with Children's Suggestibility" in Mitchell Eisen, Gail S. Goodman \& Jodi A. Quas, eds., Memory and Suggestibility in the Forensic merview (Hillsdale, N.J.: Erlbaum, 2001) 85 [Saywitz \& Lyon, "Children's Suggestibility"].

Carole Peterson \& Melody Grant, "Forced-choice: Are Forensic Interviewers Asking the Right Questions?" (2001)33 Canadian Journal of Behavioural Science 118. Investigators should clearly avoid yes/no questions with children. While it would appear that children generally have a "yes" bias, in some cases some children may have a "no" bias. There may be a greater role for this type of question in crossexamination, though triers of fact should be cautious about placing much weight on answers to these questions. (1999) 3 Applied Developmental Science 16. (Washington D.C.: ABA Centre on Children and the Law, 1999). 
may change their answers, ${ }^{22}$ as they are more likely to be deferential to what they perceive to be the adult's beliefs. ${ }^{23}$

There is an interesting body of research about honesty. Some of this research involves asking people, most often university students, about how often and when they lie, that is. deliberately make a false statement with the intent to deceive the listener. The frequency of lying depends both on personality factors as well as contextual factors. There are no reliable gender differences in frequency of lying, though males and females tend to lie about different things. Everyone tells lies, at least about relatively unimportant matters. In some contexts, lying may be very common. For example, in one study 90 percent of university students admitted that they would be willing to tell a lie to a prospective date to get that person to agree to go out with them. Lying to a spouse is generally less common than lying to a stranger, at least in part because people sense that there is a higher likelihood of a lie being discovered by a spouse, and also because the consequences of being caught lying to a spouse in terms of its effect on the relationship will be much greater. ${ }^{24}$

There is another type of research that puts people into a position where they may be tempted to lie and then studies whether they will do so. This type of research is done quite frequently with children, for example by putting them in a position where they may feel that they will get into "trouble" for what they have done. In some of these studies, as many as $\mathbf{8 0}$ percent of children will lie, though in these experimental situations there are methods of substantially reducing the incidence of lying, for example by having children promise to tell the truth before questioning them. ${ }^{3}$

There is no research about the honesty of children compared to adults. For a variety of ethical and practical reasons, it is virtually impossible to meaningfully conduct this type of research, as children and adults have very different motivations to lie. While the research about lying behaviour in various social context and laboratory situations is interesting, it provides little insight into the question of how frequently people lie in court. There is clearly a need for more research that is forensically based.

Psychological research about children's capacities and behaviours is valuable and provides useful insights for those who work in the justice system. It is, however, also important to appreciate that research identifies general tendencies, and judges and others in the justice system deal with individual cases in specific factual contexts.

\section{ReSEARCh ON JUdging CRE.dibIL.JTY aNd Detecti.g Lies}

The research about how good different observers are at detecting lies is distinct from, though related to, research about lying. Many of those who undertake credibility assessments,

:2 Maggie Bruck, Stephen J. Ceci \& Helene Hembrooke. "The Nature of Children's True and False Narratives" (2002) 22 Developmental Review 520.

"Saywitz \& Lyon, "Children's Suggestibility," supra note 16

24 Bella M. DePaulo \& Deborah A. Kaslyy. "Everyday Lies in Close and Casual Relationships" (1998) 74 J. Personality \& Social Psychology 63.

is Nicholas Bala et al. "A Legal \& Psychological Critique of the Present Approach to the Assessment of the Competence of Child Witnesses" (2000) 38 Osguode Ilall L.J. 409. 
in court or elsewhere, base their assessments on the belief that the demeanour of a person will provide clues as to whether or not the person is lying. For example, a witness's physical mannerisms (for example, avoiding eye contact) or speech patterns (stuttering) may be taken by an observer to be markers of the intent to deceive. ${ }^{26}$ This is premised on the assumption that, if a person tells a lie, this will have a psychological impact on the person, which will have observable physiological or behavioural consequences for that person. Credibility assessments based on demeanour are, however, very problematic. One difficulty in the forensic context is that the person assessing credibility lacks knowledge of the ordinary behaviour and speech patterns of the witness, so that it is difficult to determine whether the witness is acting atypically. Further, psychological research reveals that there are few specific behaviours or mannerisms that are reliable indicators of deception. ${ }^{27}$ Those who are lying do not typically show clear signs of nervousness, such as gaze aversion and fidgeting, as is commonly thought. Research has shown that suspects who are lying in high stakes situations (such as police questioning or while testifying), typically do not display stereotypical nervous behaviours such as gaze aversion, increased speech disturbances or increased movements. ${ }^{28}$ While there are a few behaviours that are reliably (but not universally) correlated with deception, such as eye blinks (people tend to make fewer eye blinks when they are lying) and microexpressions (fleeting changes in facial expression), ${ }^{29}$ these behaviours are difficult for an untrained observer to detect, and would be difficult for a judge or juror to observe in a court room setting. While appeal courts consistently instruct judges that they are not to rely on witness demeanour when assessing credibility, ${ }^{30}$ jurors may consider the demeanour of a witness while testifying in assessing credibility, ${ }^{31}$ and there is some disturbing research that suggests that jurors may find physically attractive witnesses more credible than unattractive witnesses. ${ }^{32}$

Particularly when upset, truth tellers often tell their stories in an unstructured manner and provide extraneous details. Because truthful people are not as concerned with impression management as deceivers, a truthful statement may actually be more likely to contain information that is inconsistent with general stereotypes of truthfulness, such as making spontaneous corrections or admitting to a lack of memory. ${ }^{33} \mathrm{~A}$ judge who relies on stereotypes of lying behaviour or the facial expressions, mannerisms or patterns of speech

: G.T.G. Seniuk \& J.C. Yuille, Fact Finding and the Judiciany (Saskatoon: Commonwealth of Learning, 1996).

Amina Memon, Aldert Vrij \& Ray Bull, Psychology and Law: Truthfulness, Accuracy and Credibility. 2d ed., (Chichester: John Wiley and Sons, 2003) at II.

See e.g. Samantha Mann, Alden Vrij \& Ray Bull, "Suspects, Lies and Videotape: An Analysis of Authentic High-Stake Liars" (2002) 26 L.aw \& Human Behaviour 365; and Jeremy A. Blumenthal, "A Wipe of the Hands, A Lick of the Lips: The Validity of Demeanour Evidence in Assessing Witness Credibility" (1993) 72 Neb. L. Rev. I157.

Bella M. DePaulo et al., "Cues to Deception" (2003) 129 Psychological Bulletin 74.

Sec e.g. Norman, supra note 7, Finlayson J.A.; and R.v. P.P. (S.H.) (2003), 216 N.S.R. (2d) 66 (C.A.). See e.g. Laurentide Motels Lid. v. Beauporl (Ville of). [1989] I S.C.R. 705 at 799, L'Heureux-Dubé J.; and David C. Day, "Memories are Made of This" (1998) I6 Can. Fam. L.Q. 363.

$12 \quad$ Memon, Vrij \& Bull, supra note 27 at 41

is $\quad$ ibid. at c. 2. 
of a witness may well be misled, and may, for example, assess as dishonest a witness who is upset or nervous. ${ }^{34}$

Misconceptions and a lack of information as to content and presentation of truthful statements make it especially difficult for those in the justice system to accurately assess the credibility of child witnesses. When people are asked to discriminate adult liars from truth tellers in research studies, most people perform only slightly better than chance on the basis of demeanour. ${ }^{35}$ In laboratory research studies, police officers with more experience generally do not perform better than officers at the start of their careers in correctly identifying liars, though experienced officers are more confident about their judgements. ${ }^{36}$ While police officers are trained in questioning suspects and witnesses, most police officers do not have specific training in lie detection. Some studies suggest that highly trained law enforcement officers, such as secret service agents, do perform better at lie detection than other groups, ${ }^{37}$ and that training can help to improve the ability to detect very subtle clues about deception. ${ }^{38}$ Even the most highly trained and successful professional groups generally perform less accurately at lie detection than trained operators using polygraphs. Psychological research on lie detection suggests that based on observation of witnesses, most adults, including justice system professionals like police officers, at best tend to distinguish between adult truth and lie tellers at only slightly above chance levels.

There is relatively little research about the accuracy of justice system professionals in assessing honesty of children. Research studies of mock jurors have generally found that women find child witnesses more credible than men."

There are mixed findings on the impact of a child's age on perceived credibility. In some studies a negative bias against child witnesses was found when the child witness was merely an observer and not the victim of the crime. ${ }^{40}$ Other studies, however, have found that witness age has no impact on the assessment of credibility. Among mock jurors, younger children are generally considered to be more credible than older children, when the child witness is a victim. ${ }^{11}$ Psychological research indicates that younger children are perceived to be more

Paul Ekman, Telling Lies: Ches to Deceit in the Marketplace. Pollics. and Marriage (New York: W.W. Norton, 1992) at 285: Kirk Makin. "Sclıonl Days for Judges" ('ancedian Lawyer 26:9 (August 2002) 30 .

" Senuik \& Yuille, supra note 26

ช. B.M. DePaulo \& R.L Pfeifer, "On the Job Experience and Skill at Detecting Deception"(1986) 16 Journal of Applied Social Psychology 249; and Samantla Manı. Alderı Vrij \& Ray Bull, "Detecting True Lies: Police Officers' Ability to Detect Suspects' l.ics" (2004) 89 J. App. Psych. 137. Paul Ekman, Maureen O'Sullivan \& Mark G. Frank. "A Few Can Catch a Lia" (1999) 10 Psychological Science 263.

“ Mark G. Frank \& Thomas llugh Feeley. "To Calch a Liar: Challenges for Research in Lie Deteclion Training" (2003) 31 Journal of Applied Communication Rescarch 58.

1" Bette L. Bottoms \& Gail S. Goodman. "Perceptions of Children's Credibility in Sexual Assault Cases" (1994) 24 Journal of Applied Social Psychology 702

1". See e.g. Gail S. Goodman et al. "When a Child Takes the Stand: Jurors" perceptions of children's eyewitness Testimony" (1987) I I Law and Human Behavior 27; Michacl R. L cippe \& Ann Romanczyk "Children on the Witness Stand: A Communication/Persuasion Analysis of Jurors' Reactions to Child Witnesses" in Stephen J. Ceci, Michael P. Toglia \& David F. Ross, eds.. Children's Eyewitness Memon' (New York: Springer-Verlag, 1987) 155.

"Bottoms \& Goodman, supra note 39. 
credible than adults. Female mock jurors rate children as more credible and are more likely to convict the accused based on the testimony of a child than are male jurors. ${ }^{42}$

It is now recognized that investigators should be trained to use non-suggestive techniques when questioning child witnesses. The importance of such training was clearly illustrated in an American study where professionals experienced in credibility assessment, including judges, social workers, prosecutors, research psychologists and mental health professionals, were shown videotapes of children being interviewed about abuse allegations. These professionals regarded the children whose reports were the product of suggestive prior interviewing as credible and believable, whereas reports that were actually accurate were regarded as less believable and credible. ${ }^{43}$ As a result of the repeated interviews, the false stories that were videotaped came to resemble true stories in terms of the number of details mentioned, spontaneity of ulterances, number of new details, consistency across narratives, elaboration of details and the cohesiveness of the narrative. ${ }^{44}$ This likely contributed to the inaccuracy of assessment.

Further, when children believe what they are saying, as may be the case when suggestive, investigating questioning techniques are used, it can be difficult to detect errors in narratives and thus credibility assessment can be compromised. . $^{\text {s }}$

Surveys of attitudes have found that mock jurors and members of the legal profession believe that compared with adult witnesses, child witnesses are less able to provide accurate testimony because they have inferior memory ability and are more suggestible than adults. Yarmey and Jones ${ }^{46}$ surveyed potential jurors, psychologists, legal professionals, law students and college students about attitudes regarding the reliability of a hypothetical child's testimony and found less than half of any group felt the child would respond accurately. The majority of potential jurors believed that the child would likely be quite suggestible. Other survey studies of mock jurors and lawyers indicate that children are believed by adults to be more trustworthy and sincere, but less cognitively competent and more susceptible to suggestion. ${ }^{47}$

נ: Jessica Leibergoll Hamblen \& Murray Levine, "The Legal Implications and Emotional Consequences of Sexually Abused Children Testifying as Victim-Witnesses" (1997) 21 Law \& Psychol. Rev. 139.

"Stcphen J. Ceci es al., "Repeatedly Thinking About Non-events" (1994) 3 Consciousness \& Cognition 388

4T This study makes clear the importance of videotaping all investigative interviews to preserve a record of questioning and changes in a child's story over interviews. The study also sheds some light on the very challenging nature of some cases, such as situations where a child may have been repeatedly subjected to suggestive questioning by a parent before a report is made to investigators: see e.g. Nicholas Bala \& John Schuman, "Allegations of Sexual Abuse When Parents Have Separated" (1999) 17 Can. Fam. L.Q. 191. Bruck, Ceci \& Hembrooke, supra note 12 at 144.

"A. Danicl Yarmey \& Hazel P. Tressillian Jones, "Is the Psychology of Eyewitness Identification a Matter of Common Sense?" in Sally M.A. Lloyd-Bostock \& Brian R. Clifford, eds., Evaluating Wismess Evidence: Recent Psychological Research and New Perspectives (Chichester. England: Wiley, 1983) 13.

17 See e.g. John C. Brigham \& Stacey A. Spier, "Opinions Held by Professionals Who Work with Child Witnesses" in Helen Dent \& Rhonda H. Flin, eds., Children as Wirnesses (Chichester, England: Wilcy, 1992) 93: G.S. Goodman et al., "Determinants of the Child Victim's Perceived Credibility" in S.J. Ceci, D.F. Ross \& M.P. Toglia, eds. Perspectives on Children's Testimony (New York: Springer-Verlag. 1989) 1: M.R. Leippe et al., "The Opinions and Practices of Criminal Attorneys Regarding Cliild 
While there is a considerable amount of research about the attitudes and assessment skills in regard to child witnesses of mock jurors and professionals like police regarding child witnesses, there is very little research that has involved judges. the key decision-makers in the justice system.

\section{Canadian JuRISPRUdence on Credibility ASSESSMENT OF CHIL.d Witnisses}

Until late in the twentieth century, Canadian judges tended to regard a child's evidence as inherently suspect. This was, for example, reflected in a common law rule that required a jury to be warned of the "inherent frailties" in the evidence of any child under the age of fourteen. The basis for this rule was explained by Judson J. in the Supreme Court of Canada in 1962 in $R$. v. Kendall:

The basis for the rule of practice which requires the judge to warn the jury of the danger of convicting on the evidence of a child, even when sworn as a witness. is the mental immaturily of the child. The difficulty is fourfold: I. His capacity of observation. 2. His capacity of recollection. 3. His capacily io undersland questions put and frame intelligent answers. 4 . His moral responsibility. ${ }^{48}$

This judicial skepticism about children's testimony, especially in sexual abuse cases, made it very difficult to obtain a conviction in cases where children were victimized, since these offences typically occur in private and there is often no physical evidence of abuse to support the allegation. It was of course very unfair to individual children to have this type of warning in every case.

In the late 1980 s, the Canadian legal system began to change, with the reform of both statutory and common law rules governing child witnesses." By the time of the 1990 Supreme Court of Canada decision in $R$. v. B. $(G).)^{50}$ there was a recognition that the testimony of children should not be assessed in the same way as the testimony of adults. Although psychological research was not cited by the Court, the Court displayed much more appreciation of the true nature of children's testimony. Justice Wilson wrote:

[A] flaw, such as a contradiction, in a child's testimony should not be given the same effect as a similar flaw in the testimony of an adult... While cliildren may not be able to recount precise details and communicate the when and where of an event with exactitude, this does not mean that they have inisconceived what happened to them and who did it. ${ }^{\text {sI }}$

In 1992 in R.v. R.W. ${ }^{52}$ the Supreme Court overturned its 1962 decision in Kendall, abolishing the common law rule about the need for a warning about the "inherent frailty" of

Eyewitnesses: A Survey" in Ceci. Ross \& Toglia, ibid. at 100: lecippe \& Romanczyk, supra nole 40: David F. Ross ef al. "The Child in the Eyes of the Jury: Assessing Mock Juror's Perceptions of tlic Child Witness" (1990) 14 Law \& lluman Behavior 5.

[1962] S.C.R. 469 at 473 [footnote omitted].

See Bala. "Double Victims," supra note I

[1990] 2 S.C.R. 30.

Ibid. at 55 .

[1992] 2 S.C.R. 122 [R.W'] 
the evidence of every child witness, rejecting "the stereotypical but suspect" views about child witnesses. To reinforce the effect of R.W., in 1993 Parliament enacted s. 659 of the Criminal Code, ${ }^{53}$ expressly abrogating the common law rule that it is "mandatory for a court to give the jury a warning about convicting an accused on the evidence of a child." 659 and more recent judgments reflect a judicial recognition that children can be as reliable in what they recall about an incident as adults, albeit they may not be able to describe events in as much detail in "free recall" as adults and may be unable to ansiver some kinds of questions that adults can. This was again recognized by the Supreme Court of Canada in 1997 when Cory J. acknowledged:"s

[T]hat the peculiar perspectives of children can affect their recollection of events and that the presence of inconsistencies, especially those related to peripheral marters, should be assessed in context. A skilful cross-examination is almost certain to confuse a child, even if she is telling the Iruth. That confusion can lead to inconsisteneies in her testimony. Although the trier of fact must be wary of any evidence which laas been contradicted, this is a matter which goes to the weight ... and not to its admissibility.

Section 659 of the Criminal Code and the Supreme Court jurisprudence do not create a presumption in favour of a child's testimony.

As recognized by the Ontario Court of Appeal in its 1994 decision in $R$. v. Stewart, ${ }^{56}$ the evidence of children should not be compared to what one might expect of an adult witness, but it must be carefully assessed. Like adults, children can lie or be mistaken. Justice Finlayson observed: ${ }^{37}$

\begin{abstract}
[W]e must assess witnesses of tender years for what they are, children, and not adults. We should not expect them as witnesses to perform in the same manner as adults. This does not mean, however, that we should subject the testimony of children to a lower level of scrutiny for reliability than we would do adults. My concern is that some trial judges may be inadvertently relaxing the proper level of scrutiny to which the evidence of children should be subjected. The changes to the evidentiary rules were intended to make child evidence more readily available to the court by removing the restraints on its use that existed previously but were never intended to encourage an undiscriminating acceptance of the evidence of children while holding adults to higher standards.
\end{abstract}

While Stewart illustrates that appeal courts will reverse an assessment of credibility by a trial judge, the appeal courts have accepted that they should generally defer to the credibility assessment of the trial judge or jury, as these triers of fact have the advantage of observing the demeanour of witnesses. This deference is more important for child witnesses, who may be more expressive than adults and for whom non-verbal communication may be especially

st R.S.C. 1985 , c. C-46.

s4 Enacled as S.C. 1993, c. 45, s. 9.

"R. v. F. (C.), [1997] 3 S.C.R. 1183 al para. 48 . See also R. v. A.W.E. [1993] 3 S.C.R. 155 aflirming that "the testimony of children ... should not be evaluated on the same slandards as that used in issessing evidenee given by adults. Rather a flexible common sense approach to the evidence of children should be employed" (Cory J. at para. 78).

3. (1994), 18 O.R. (3d) 509 (C.A.).

$" \quad$ bid. at 517 . Similarly see e.g. R. v. C. (F.) (1996), 104 C.C.C. (3d) 461 (Ont. C.A.); R. v. Minuskin (2003), 68 O.R. (3d) 577 (C.A.); R. v. C. (S.R.) (1997), 86 B.C.A.C. 256 (C.A.); R. v. L.A.P. (2000), I50 Man. R. (2d) 247 (C.A.). 
important. This was, for example, recognized by the British Columbia Court of Appeal in $R$. v. D.L.L., ${ }^{53}$ where the Appeal Court emphasized the role of the trial judge in assessing the credibility of two child witnesses and ruled that it would only reverse a credibility finding if satisfied that the trial court "manifestly abused"s9 its discretion.

\section{Current Project: Two Studies on JUDICIAI. ASSESSMENTS OF CHILD WITNESSES}

The authors are part of a team that is involved in a long-term research program about child witnesses. As part of this program a number of studies have been done involving different actors in the justice system. In this article, we are focusing on the responses of judges in two studies.

\section{A. Study on accuracy of Justice Professionais in ASSESSING HONESTY OF CIIL.DREN}

One study was intended to learn how accurate different professionals and law students are at determining whether a young child is telling the truth or lying.

Participants at a number of different professional educational programs that were held in different parts of Canada in 2001 to 2003 were shown video clips of three girls testifying in a mock court situation. The girls in the video clips, aged 4 and 5 , had been prepared by their mothers to come to "testify" about events that are common, but not universal, experiences for children: going to the hospital, attending a wedding and going skiing. Two of the girls testified about events that actually happened to them, while a third girl, with the aid of her mother, prepared a fabricated story as she had never participated in the activity (skiing). The children were brought to a psychology lab that was decorated as a courtroom where graduate students, gowned as lawyers and a judge, asked the children questions. The "judge" began by asking the child questions that are typically asked at a competency inquiry conducted pursuant to s. 16 of the Canada Evidence Act ${ }^{60}$ about the child's understanding of the meaning of truth and lying, and about the significance of making a promise to tell the truth. Regardless of the answers, each child was asked by the judge to promise to tell the truth, which all did. The "prosecutor" (who met with the child prior to the child coming into the "court") then asked the child some non-leading questions about the event, to try to get the child to give a complete description of the events. Each child was then "cross-examined," though the participants in this study were not shown the video tapes of this portion of the testimony. ${ }^{.1}$

After being shown the video clip of the competency inquiry for a child, participants were asked to complete a questionnaire about whether they considered that the child was competent to testify. Participants were then shown the video clip of the testimony of that child and completed a questionnaire about whether they thought that she was telling the truth

"1 The authors are using the cross-examinations in ongoing studies. In this initial study, the crossexaminations were not used due to a concern that they would complicate and lengthen the exercise. 
or had fabricated the story, and how confident they were in this assessment. The video clips that were shown to the participants in the study were between six and ten minutes for each child, with the five year old (who was the only liar in the group) testifying the longest. The participants were shown the video clips prior to any discussion of child witness issues at the program.

A total of 42 law students, 39 child protection social workers, 39 judges and 27 other professionals working with the justice system (including police, lawyers, social workers not in child protection, doctors and victim-witness assistance workers) watched the video clips and completed the questionnaires. Among the judges there was no statistically significant difference between males and females in the accuracy of the assessments of the children.

The results of the accuracy of the assessments of whether the children were telling the truth or had made up a story are set out in Table 1:

Table 1: Accuracy of l.ie Detection for Court Simulation Video Clips

\begin{tabular}{|l|c|c|c|c|c|}
\hline Profession & $\begin{array}{c}\text { Number of } \\
\text { Participants }\end{array}$ & $\begin{array}{c}\text { \% accuracy } \\
\text { Girl 1:4yrs. } \\
\text { (truth about } \\
\text { hospital visit) }\end{array}$ & $\begin{array}{c}\text { \% accuracy } \\
\text { Girl 2:4yr. } \\
\text { (truth about } \\
\text { wedding) }\end{array}$ & $\begin{array}{c}\text { \% accuracy } \\
\text { Girl 3:5yr. } \\
\text { (lying about } \\
\text { sking) }\end{array}$ & $\begin{array}{c}\text { Overall } \\
\text { Accuracy (\%) }\end{array}$ \\
\hline $\begin{array}{l}\text { Law } \\
\text { Students }\end{array}$ & 42 & 59 & 22 & 51 & 44 \\
\hline Judges & 39 & 100 & 44 & 54 & 56 \\
\hline $\begin{array}{l}\text { Child } \\
\text { Protection } \\
\text { Wotkers }\end{array}$ & 39 & 83 & 15 & 36 & 54 \\
\hline $\begin{array}{l}\text { Other } \\
\text { Professionals }\end{array}$ & 27 & 84 & 44 & 32 & 51 \\
\hline
\end{tabular}

Overall the judges and other professionals had very similar results, correctly identifying the child who was telling lies and those who were telling the truth slightly above chance levels. The law students were significantly less accurate than the other groups at accurately assessing whether or not the child was lying. ${ }^{62}$ These results suggest that professional experience with observing witnesses may play a role in credibility assessment, but that judges do not seem to be more accurate than social workers or police officers in assessing honesty, and that none of the groups could perform the task presented in our study very well. Interestingly, the finding of this Canadian study on child witnesses that professionals perform at slightly above chance levels in assessing honesty based on viewing relatively short video clips, is consistent with a number of similar studies of justice system professionals in other jurisdictions assessing adult witnesses. ${ }^{63}$

$\because \quad$ When law students are compared to all other professionals, $p=0.029$; when compared to judges and social workers only, $\mathrm{p}=\mathbf{0 . 0 1 4}$.

6: Memon, Vrij \& Bull, supra nutc 27 at 26-27 
It should be emphasized that while these results suggest that judges may not be better than other justice system professionals when assessing credibility, it would be quite wrong to conclude that judges perform at only slightly above chance levels in courtroom settings when making decisions about cases involving the assessment of the honesty of child (or other) witnesses. ${ }^{64}$ Although this study was based on a commonly used research method of assessing the accuracy of lie detection of adult subjects, it is a challenging and somewhat artificial test of what judges actually do in court. This was a low stakes situation for the participants, who may not have been as careful and thorough as they would be in their professional work. This was also a low stakes situation for the child witnesses who may therefore have been less likely to have their demeanour affected by their honesty or lack thereof. Perhaps most significantly, the video clips that formed the basis for this assessment are relatively short and the participants had no evidence about the context of the testimony. A judge in court would generally have a longer period and more evidence to utilize in assessing the credibility of a child witness. A judge would be looking at all of the evidence in the context of the situation, not just a short acontextual video clip. As well, because this is not an actual situation, the judge did not have the opportunity to assess the testimony in cross-examination and to assess other indicia of reliability and credibility. ${ }^{\text {os }}$ All of these factors may contribute to a difficulty in accurately assessing the honesty of the children. The participants were largely relying on the demeanour of the witnesses when assessing honesty, and this study confirms that this is often a highly unreliable guide to honesty.

\section{B. Study on Judicial Perceptions of Credibility of Child Witnesses}

As discussed above, while a number of studies have examined how accurate justice system professionals are at lie detection and then attempted to correlate that with perceptions of credibility assessment, no previously reported study has actually asked judges to explain how they assess the credibility of witnesses or how they compare the credibility of child and adult witnesses.

in Overall, rescarch on lie detection suggests that most individuals. including judges and police olticers, are nol very good at detecting lies based simply on observing strangers (w/iether children or adults) lell a story. If lying were readily delected, it would be unlikely to persist as a common behaviour Many police officers, for example, believe that they are quite accurate in detecting lies. Often. however. their accuracy is not based on the assessment of the honesty of a particular witness, but rather because the statements contradict other information known to be reliable. Thus a witness who denies touching an object that has his fingerprints on it is obviously lying. However, in the absence of the fingerprints, it may have been impossible to accurately determine that the denial was a lie. Repeated experiences of this type inay produce false beliefs in the ability to detect lies simply by listening to what people say. This might explain why the ability to delect lies does not increase with time on the job for police officers, but their conlidenee in their lie detection abilities does increalse with experience. Sec $\wedge . M$ Leach ef al. "Intuitive Lie Detection of Children's Deception by I.aw Enforcement ()flicials and University Students" Law \& Human Bchaviour [fortheoming 2005]

One of the few studies of how accurately police officers assessed the credibility of aclual suspects being interrogated by other officers on a videotape revealed that the oflicers did signilicantly better in this "real life" exercise than with the nore common laboratory based studies of "low stakes" siluations, though it also revealed that accuracy and confidence are not signiticantly correlated: Samantha Mann. Aldert Vrij \& Ray Bull, "Detecting True I. ies: Police Officers" Ability to Detect Suspects" I.ics" (20014) 89 J. App. Psych. 137. 
We report here on some of the most significant data from a study that the authors conducted with Canadian judges, asking them about their perceptions about child and adult witnesses. Three of the authors of this study (Bala, Lee and Lindsay) were invited to present at judicial education programs in a number of jurisdictions in Canada in 2002 and 2003 on a range of different topics, including programs that involved the study described above of the assessment of credibility of child witnesses. We used the opportunity provided when presenting at judicial education programs on subjects other than programs involving the study of the assessment of credibility of child witnesses described above to distribute questionnaires about child witnesses. Since we were not certain of exactly how many attendees were given these questionnaires, we are not certain of the response rate. However, the questionnaires took 20 to 30 minutes to complete, and judges are busy people, so the response rate was not high, in the range of 10 percent to 20 percent.

We had 38 respondents from a number of jurisdictions in Canada - 27 male, 10 female and I not indicated. Twenty judges were appointed by provincial or territorial governments and always sit without a jury, while 18 were federally appointed superior court judges, who can hear trials alone or sit with a jury.

The survey asked a number of questions about perceptions and practices in regard to child witnesses. Most questions required respondents to circle answers from a number of choices, though a few questions allowed for open-ended comments. For several questions respondents were asked to compare how they generally viewed children of different ages in comparison to adult witnesses. These questions covered issues such as suggestibility, leading questions, memory and perceptions of honesty.

In regard to suggestibility, judges were asked:

What percentage of witnesses of the following ages umimemionally make false statements in court duc to false memories generaled by suggestive pre-court interviewing? ${ }^{66}$

The results are set out in Table 2. Judges generally perceive adults as being less susceptible than children to the suggestive effects of pre-court interviews by investigators or discussions with family or others. They also believe that suggestive effects are more likely the younger the child.

is. For each question asking for percentage tesponses, respondents were given a scale with percentages marked at 10 percent intervals, and asked to circle the value closest to the percentage they believed would apply. 
Table 2: Judicial Perception of Suggestibility

\begin{tabular}{|c|c|}
\hline Age Group (years) & $\begin{array}{c}\% \text { of Witnesses Perceived } \\
\text { as Suggestible }\end{array}$ \\
\hline $2-5$ & 47 \\
\hline $6-10$ & 42 \\
\hline $11-13$ & 33 \\
\hline $14-17$ & 24 \\
\hline Adults - 18 yrs and older & $18^{*}$ \\
\hline
\end{tabular}

Judges were asked about their perceptions of the effect of leading questions asked in court on the testimony of children:

What percentage of witnesses of the following ages unintentionally make false stalements in court because they are acquiescing to leading questions asked in coun?

The results set out in Table 3 reveal that judges perceive adults as significantly less influenced by leading questions than children, and this perception also correlates with the age of the child.

Table 3: Judicial Perception of Influence of Leading Questions

\begin{tabular}{|c|c|}
\hline Age Group (years) & $\begin{array}{c}\text { \% or Willuesses Perceived as } \\
\text { Influenced by Leading } \\
\text { Questions }\end{array}$ \\
\hline $2-5$ & 68 \\
\hline $6-10$ & 63 \\
\hline $11-13$ & 51 \\
\hline $14-17$ & 39 \\
\hline Adults - 18 yrs and older & $29 *$ \\
\hline
\end{tabular}

Judges were asked about their perceptions of the reliability of the memory of witnesses of different ages:

What percentage of witnesses, when properly questioned, unintentionally make false statements in court ( $\mathrm{f}$. report inaccurately with no intent to mislead) about key elements/peripheral details of the events in question due to inaccurate memory?

As set out in Table 4, judges generally perceive that younger children are significantly more likely than adults to make errors in their testimony due to the limitations of the memory 
capacity of children, with more errors for peripheral details than for central elements of their testimony.

Table 4: Judicial Perception of Memory Accuracy for Key Elements and Peripheral Delails

\begin{tabular}{|c|c|c|}
\hline Age Group (years) & Key Elements & Peripheral Details \\
\hline $2-5$ & 56 & 63 \\
\hline $6-10$ & 50 & 59 \\
\hline $11-13$ & 42 & 55 \\
\hline $14-17$ & 33 & 47 \\
\hline Adults & $24^{*}$ & $42^{\circ}$ \\
\hline
\end{tabular}

* indicates significant difference ${ }^{69}$

The judges were asked a question about their perceptions of the honesty of witnesses:

What percentage of witnesses of the following ages lie in court (intentionally make false statements)?

Although children are perceived as more likely than adults to make errors in their testimony due to limitations of memory and communication skills, as well due to the greater suggestibility of children, judges perceive children as more honest than adults. As set out in Table 5, adults are perceived by judges as more likely to lie in court than children, and as age increases, the perception of frequency of lying increases.

Table 5: Judicial Perception of Honesty

\begin{tabular}{|c|c|}
\hline Agc Group (years) & $\begin{array}{c}\text { Percentage of Witnesses Perceived } \\
\text { 1o lie in Court }\end{array}$ \\
\hline $2-5$ & 11 \\
\hline $6-10$ & 13 \\
\hline $11-13$ & 18 \\
\hline $14-17$ & 25 \\
\hline Adults & $32^{\circ}$ \\
\hline
\end{tabular}

- indicates significant difference ${ }^{70}$

Judges were also asked about the incidence of children being asked questions that are developmentally inappropriate:

What percentage of child witnesses are asked questions that they are incapable of answering due to confusion or inability to understand questions by different professionals?

6.) Adults are perceived to make less false statements (bolh key and peripheral) than children (key: all groups. $p<0.001$; peripheral: $2-5$ yrs., $p<0.001$; $6-10$ yrs., $p<0.001$; $11-13$ yrs., $p<0.001$; $14-17$ yrs., $p=0.002]$.

3.1 As age increases, perception of lying in court also increases: $p<0.001$; Adults are perceived to lie in court more than children [2.5 yrs., $p<0.001 ; 6-10$ yrs., $p<0.001 ; 11-13$ yrs., $p=0.001$; $14-17$ yrs., $p=0.005]$. 
As set out in Table 6, judges believe that many child witnesses are asked questions that are developmentally inappropriate. When questioning by different justice system professionals is examined, judges perceived that defence counsel are more likely to ask more inappropriate questions than other professionals, while child protection workers are thought to ask the fewest number of inappropriate questions.

Table 6: Judicial Perception of Developmentally

Inappropriate Questioning of Child Witnesses

\begin{tabular}{|l|c|}
\hline \multicolumn{1}{|c|}{ Profession } & $\begin{array}{c}\text { Percentage of Child Witnesses asked } \\
\text { Inappropriate Questions }\end{array}$ \\
\hline Crown & 45 \\
\hline Defence & $62^{*}$ \\
\hline Police & 44 \\
\hline Child Protection Worker & 31 \\
\hline Vietim/Witness Worker & 31 \\
\hline Judge & 31 \\
\hline
\end{tabular}

* indicates significant difference

One judge offered a comment about the need for greater respect by appellate courts for the decisions of trial judges about the control of questions that are posed to child witnesses:

Appellate courts should not interfere with (as much) exercise of trial judge's discretion to curtail improper or inadequate questioning by lawyers (crown and defence).

Another judge expressed concerns about the manner in which defence counsel question children.

Intimidation is the strongest defence tactic and should be eliminated in fairness.

The responses to this question suggest that professionals in the justice system, including judges, should receive more education about communication with children, and the asking of developmentally appropriate questions. As noted by one of the participating judges:

The learning and acquiring of language skills should be part of a new judge's training as it relates to receiving a child's testimony into evidence.

Although there was significant variation in individual responses, contrary to previous research with mock jurors, ${ }^{72}$ there was not a significant difference between the responses of male and female judges. As well, there was no difference between the responses of superior and provincial court judges. Nor did the number of child witness cases presided over per year affect responses. Further, having children of their own did not have any consistent effect on the responses, even though one participating judge claimed: 
A questioner who has his or her own children can assess credibility of a child and/or can assess competence more reliably than non-parents. This applies to a judge as well as Crown, defence, social workers, etc.

While judges may not always accurately assess the credibility of individual witnesses, it is significant that the perceptions of the judges about the memory, suggestibility and communication abilities of children compared to adults are generally consistent with the psychological research about the capacities of child witnesses.

The judicial perceptions about the honesty of child witnesses compared to adults are especially interesting, since there is no research on this topic. Indeed it would be very difficult to conduct meaningful research about whether children actually are more honest witnesses than adults, and the relative honesty of children and adults would undoubtedly be affected by the context. The judges' perception about the relative honesty of children in the context of criminal court proceedings is, however, very interesting. Honesty is not the only factor in weighing the evidence of a witness. As observed by one judge in this study:

There is litte or no co-relation between age and credibility except for the very young witness (2-5). Credibility is taken as combining several factors of course, not just "honesty."

\section{Discussion OF Rrsults}

Assessing the credibility of witnesses - deciding how much to rely on their testimony is central to the trial process. The assessment of credibility is an inherently human and imprecise enterprise. Although professionals who work in the justice system can, and should, have education about credibility assessment, our criminal justice system is premised on the notion that in serious cases an accused person has the right to have lay persons assess credibility, but with the important safeguard that there is to be a conviction only if each of the jurors is satisfied beyond a reasonable doubt as to the guilt of the accused.

The studies reported here offer some important insights into the way in which judges in Canada assess the credibility of child witnesses. These are, however, the first studies of this kind involving judges to be undertaken anywhere in the world, and the sample sizes are not large. The results must be viewed as preliminary and there is clearly a need for more work in this area.

In our first study we tested the accuracy of judges, other professionals who work in the justice system and law students in assessing the honesty of three young children. Although in the challenging test that we used, the accuracy of judges in assessing whether the children were lying or telling the truth was only slightly above chance level, the performance of judges was comparable to other professionals who work in the justice system, and significantly better than law students. One might expect that the law student group would not perform worse than jurors, which suggests that judges and other professionals may have more skill in accurately assessing credibility than jurors and other lay persons. The training and experience of the judges and other professionals who work in the justice system would seem to have a positive effect on their ability to assess credibility. On the other hand, even the heightened ability of experienced professionals does not result in the ability to readily determine truthfulness based solely on a witness' demeanour. 
We noted that the test we employed was challenging, and participants had much less information and opportunity to assess credibility than they would have in court. Thus while this study clearly establishes that judges are not "human lie detectors," it would be wrong to conclude that they operate at only slightly above chance levels in the court. The results of this study, which illustrate the difficulties in accurately assessing the credibility of individual witnesses, however, are consistent with the Canadian model of criminal justice, where an important safeguard of liberty is that an accused can only be found guilty if the trier of fact is satisfied beyond a reasonable doubt, based on all of the evidence, of the guilt of the accused.

In our survey of judicial attitudes, we did not find any biases against child witnesses, and the relatively small number of judges who wrote in comments seemed generally sympathetic to the challenges faced by child witnesses in testifying in the criminal justice process.

Somewhat surprisingly, the sex of judges did not seem to affect either the accuracy of assessments of child witness veracity or attitudes towards child witnesses. This is interesting because feminist theory ${ }^{73}$ and research into attitudes of mock jurors ${ }^{74}$ clearly suggest that in general women have a more sympathetic approach to children and alleged victims of sexual assault. It may be that the professional formation of judges through legal education and years in the practice of law and judging eliminates the sex differences that are revealed in studies of attitudes of mock jurors and university students. The process of selection of judges also might have a role, with those female lawyers who "think like a man" being most likely to get appointed as judges, or those males who have a bias against child witnesses being screened out. Given the social concern about the appointment of female judges and the arguments of some that there will be a "difference" in the justice system if more women are appointed as judges, ${ }^{7 s}$ this is certainly an issue that merits further study. It should, however, be a considerable comfort to defence counsel and accused persons in cases involving child witnesses to know that the fact that the judge is female or male should not affect how the evidence of a child witness will be assessed.

Judicial perceptions of child witnesses are generally consistent with the present psychological literature. Children's memory, communication skills and suggestibility generally make them somewhat less reliable than adults. Significantly, however, judges believe that in the context of the cases that are brought before them. children are less likely to lie than adults. Of course, it is logically possible that judges are simply inaccurate in their perceptions of the relative honesty of child witnesses, but this seems unlikely. Most of the court cases in which children, especially young children, are witnesses, arise out of the alleged victimization of a child, often in the context of sexual abuse allegations. In these cases, children, unless coached by an adult, may lack the knowledge to fabricate evidence of sexual abuse. While there are concerns about the adequacy of the investigation and preparation of cases involving child witnesses, there is generally a more careful screening of

" See e.g. Carol Gilligan, In A Different looce: Psychological Theory and Itomen is Ilevelopment (Cambridge: Harvard University Press. 1982)

See e.g. discussion above of work of Bottoms \& Goodman. supra notc 39.

See e.g. Madame Justice Bertha Wilson. "Will Women Judges really make a Diflerence?" (I)9(0) 28 Osgoode Hall L.J. 507. 
cases involving child witnesses, so that cases in which children are likely to be lying may be less likely to be brought to court.

\section{IMPLICATIONS FOR THE JUSTICE SYSTEM}

One of the findings of the survey of judicial attitudes was that children are frequently asked questions that they could not reasonably be expected to answer. The vocabulary, grammar or concepts used are often developmentally inappropriate. These questions may be posed by Crown prosecutors or judges in court, or by police, for example on a videotape of an interview shown in court. Judges reported, however, that developmentally inappropriate questions are most frequently asked by defence counsel. The judicial perceptions about the inappropriateness of some of the questioning of child witnesses by defence counsel is consistent with the views of other observers. ${ }^{76}$ In fairness to defence counsel, they have a different role from the other actors in the justice system, and generally have less experience and training in questioning of children than some of the other professionals. Further, unlike such professionals as the Crown and police, defence counsel lack the opportunity to meet with a child witness prior to cross-examination in order to establish a rapport and develop comfort in communicating. Despite these differences in role and training, defence counsel and other professionals in the justice system should be expected to ask questions of child witnesses in a developmentally appropriate fashion.

It is submitted that judges have an obligation to ensure that all witnesses, including children, are asked questions in court that they can understand and meaningfully answer. Justice L'Heureux-Dubé of the Supreme Court of Canada in R. v. L.(D.O.) clearly recognized such a duty:

It is my view that ... in ... cases involving fragile witnesses such as children, the trial judge has a responsibility to ensure that the child understands the question being asked and that the evidence given by the child is clear and unambiguous. To accomplish this end, the trial judge may be required to clarify and rephrase questions asked by counsel and to ask subsequent questions to the child to clarify the child's responses. In order to ensure the appropriate conduct of the trial, the judge should provide a suitable atmosphere to ease the tension so that the child is relaxed and calm. The trial judge, in this case ... [did] nothing more than 'intervene for justice to be done. ${ }^{.77}$

More and better education is required for judges and other professionals who work in the justice system in order to help them better understand what types of questions are developmentally appropriate for children ${ }^{78}$ and to help ensure that these professionals are aware of research about credibility assessment. ${ }^{79}$

7. See e.g. Nova Scotia Department of Justice, Victim Services Division, "Child Victims and the Criminal Justice System," Child Victim Witness Program Study Report (March 1993 - June 1999), August 2000 at 74.

" [1993] 4 S.C.R. 419 at 471 [emphasis added].

7* See e.g. John Schuman, Nicholas Bala \& Kang Lee, "Developmentally Appropriale Questions for Child Witnesses" (1999) 25 Queen's L.J. 25I; and Walker, supra note 19.

". Makin. supra note 34. 
A child who is asked developmentally appropriate questions is more likely to give accurate and reliable testimony, and the trier of fact is more likely to accurately assess the child's testimony. ${ }^{80}$ Often when children are frustrated and confused by questions beyond their cognitive and developmental level, they will respond in a manner significantly different from adults. Young children in particular may become silent, irritable, fidget or respond with "I don't remember." Young children will often agree with confusing questions in an effort to minimize their confusion and frustration, not appreciating that they can ask for clarification. Omissions in testimony may also occur as a result of fear, becoming flustered due to repetitive questions and difficult cross-examination, becoming emotional as a result of disturbing testimony or questions and not being given the chance to fully describe the events as a result of questions that are too specific. ${ }^{81}$ Rather than interpreting such behaviours as indicators of deception or lack of memory, judges and other justice system professionals need to be aware of the capacities of children and the likelihood that such behaviours signify confusion and frustration rather than deception.

There are also measures that can be taken in the justice system that will help ensure that the trier of fact can fairly assess a child's testimony. For example, reducing delay in the justice system and shortening the time between the offence and the trial date will minimize the deterioration in the child's memory and will usually result in the child being a better witness. Reducing delay between reporting and trial is crucial to ensuring that a child is able to give the most complete and consistent testimony possible. While delay and loss of memory is a concern for any witness, they are more pronounced concerns with child witnesses. ${ }^{82}$ Reducing the child's discomfort with the court process is also important for fair assessment of the credibility of children, and it is thus important for the child and the Crown prosecutor to meet at least a couple of times before the child testifies, with the goal of minimizing anxiety as a result of testifying. 